[Agr. Biol. Chem., Vol. 34, No. 1, p. 95 101, 1970]

\title{
Genetic Relatedness of Yeast Strains Studied by the DNA-DNA Hybridization Method
}

\author{
By Kozo Ouchi*, Hiuga Salto and Yonosuke Ikeda \\ Institute of Applied Microbiology, University of Tokyo, \\ Tokyo
}

Received June 14, 1969

\begin{abstract}
Genetic relatedness of 14 yeast strains and 2 mold strains was studied by the DNA-DNA hybridization method. The hybridization was performed between mitochondrial-DNA-free, 32P-labeled DNA of Saccharomyces cerevisiae IAM 4009 and cold DNA of other strains. The DNA homology indices deviated considerably even among $S$. cerevisiae strains having similar GC contents, but, in general, yeast strains known to be able to mate with $S$. cerevisiae, showed high homology indices $(35 \sim 70 \%)$. Other species of Saccharomycetaceae and 6 asporogenous yeast strains exhibited values of $10 \sim 20 \%$. The relatedness suggested from these results was confirmed by the competition experiments and also by the hybridization with 32P-DNA of Candida pulcherrima IFO 0561. DNA's of Aspergillus oryzae I and Neurospora crassa IFO 6067 also exhibited low but appreciable homology indices $(5 \sim 7 \%)$. These results were discussed from the aspects of phylogenetics and also of gene conservation in microorganisms.
\end{abstract}

Taxonomy of yeasts is mainly based on morphological and physiological observations. ${ }^{11}$ These properties are generally unstable and do not fit the purpose of phylogenetic studies. Tsuchiya et al. ${ }^{21}$ proposed an immunological method based on species-specificities of somatic antigens. Another proposal is the use of guanine-cytosine (GC) content in DNA. ${ }^{3 \sim 6 !}$ This criterion has been reported to be useful for classification of Candida species ${ }^{4,6)}$ in which GC contents are divergent.

Currently, the species-specificity in micro-

* On leave from: Research Institute of Brewing, Kitaku, Tokyo.

1) J. Lodder and N. J. W. Kreger-van Rij, "The Yeasts, A Taxonomic study," North Holland Publishing Co., Amsterdam, (1952).

2) T. Tsuchiya, Y. Fukazawa and S. Kawakita, Mycopathol. et Mycol. Appl., 26, 1 (1964).

3) R. Storck, J. Bacteriol., 91, 227 (1966).

4) T. Nakase and K. Komagata, J. Gen. Appl. Microbiol., 14, 345 (1968).

5) S. A. Meyer and H. J. Phaff, J. Bacteriol., 97, 52 (1969).

6) A. Stenderup and A. L. Bak, J. Gen. Microbiol., 52, 231 (1968). organisms is discussed in terms of DNA homology. As far as fungal strains are concerned, studies from this aspect are still scarce. ${ }^{7}$ The purpose of the present study is to investigate interrelationships between the DNA homology in yeast strains and their systematic taxonomy.

\section{MATERIALS AND METHODS}

Microorganisms. Strains used in this study are listed in Table 1. Most of the strains were supplied from the Division of Type Culture Collection of this Institute. Cells of Aspergillus oryzae and DNA of Escherichia coli were gift from Drs. H. Ishizuka and H. Takahashi of this Institute.

Media. Strains, except for Saccharomyces rouxii, were grown in a medium containing, in I liter of tap water, glucose, $20 \mathrm{~g}$; yeast extract, $2 \mathrm{~g}$; polypeptone, $5 \mathrm{~g}$; $\mathrm{KH}_{2} \mathrm{PO}_{4}, 1 \mathrm{~g}$ and $\mathrm{MgSO}_{4} \cdot 7 \mathrm{H}_{2} \mathrm{O}, 0.3 \mathrm{~g}$. S. rouxii was incubated in the medium supplemented with $10 \%$

7) S. K. Dutta, N. Richman, V.W. Woodword and M. Mandel, Genetics, 57, 719 (1967). 
$\mathrm{NaCl}$. The incubation was carried out at $27^{\circ} \mathrm{C}$ for 16 to $20 \mathrm{hr}$ on a rotary shaker.

A phosphate-limiting medium used for labeling of DNA contained, in 1 liter of $0.01 \mathrm{~m}$ citrate buffer (pH 5.8), glucose, $20 \mathrm{~g}$; L-asparagine, $2 \mathrm{~g}$; casamino acid, $2 \mathrm{~g} ;\left(\mathrm{NH}_{4}\right)_{2} \mathrm{SO}_{4}, 2 \mathrm{~g} ; \mathrm{MgSO}_{4} \cdot 7 \mathrm{H}_{2} \mathrm{O}, 0.5 \mathrm{~g} ; \mathrm{KCl}$, $0.6 \mathrm{~g} ; \mathrm{CaCl}_{2} \cdot 2 \mathrm{H}_{2} \mathrm{O}, 0.33 \mathrm{~g} ; \mathrm{KH}_{2} \mathrm{PO}_{4}, 68 \mathrm{mg}$; Wickerhan's trace elements and vitamin mixture. ${ }^{81}$

Neurospora crassa was grown under the similar conditions for $24 \mathrm{hr}$ in a medium ( $\mathrm{pH} \mathrm{5.5)} \mathrm{containing,}$ in 1 liter of tap water, glucose, $10 \mathrm{~g}$; yeast extract, $4 \mathrm{~g}$; polypeptone, $5 \mathrm{~g}$; $\mathrm{Na}_{3}$-citrate $\cdot 2 \mathrm{H}_{2} \mathrm{O}, 2.5 \mathrm{~g}$; $\mathrm{KH}_{2} \mathrm{PO}_{4}$, $5.0 \mathrm{~g} ; \mathrm{NH}_{4} \mathrm{NO}_{3}, 1.0 \mathrm{~g} ; \mathrm{MgSO}_{4} \cdot 7 \mathrm{H}_{2} \mathrm{O}, 0.2 \mathrm{~g} ; \mathrm{CaCl}_{2}$. $2 \mathrm{H}_{2} \mathrm{O}, 0.1 \mathrm{~g}$ and streptomycin-sulfate, $50 \mu \mathrm{g} / \mathrm{ml}$. A young culture was inoculated to the main medium in a size of $2.5 \%$. Before inoculation, the mycelia were homogenized in a Waring blender for $2 \mathrm{~min}$.

Preparation of DNA. DNA of yeasts was prepared by the method described by Smith and Halvorson ${ }^{91}$ with slight modifications. Cells were washed twice with SSC $\left(0.15 \mathrm{M} \mathrm{NaCl}\right.$ and $0.015 \mathrm{M} \mathrm{Na}_{3}$-citrate), once with saline-EDTA-SLS $(0.15 \mathrm{M} \mathrm{NaCl}, 0.1 \mathrm{M}$ EDTA, $2 \%$ sodium lauryl sulfate, $\mathrm{pH}$ 8.0) and frozen at $-20^{\circ} \mathrm{C}$. After being thawed at room temperature, a volume of cells was suspended in an equal volume of saline-EDTA-SLS and homogenized for $2 \mathrm{~min}$ in a mechanical-cell homogenizer (Braun Co., West Germany). The homogenate was incubated first at $37^{\circ} \mathrm{C}$ for $4 \mathrm{hr}$ and then at $60^{\circ} \mathrm{C}$ for $10 \mathrm{~min}$ after the addition of $\mathrm{NaClO}_{4}$ to the final concentration of $1 \mathrm{M}$. DNA was extracted from the homogenate by shaking for $30 \mathrm{~min}$ with an equal volume of chloroformisoamylalcohol $(24: 1)$. The mixture was centrifuged at $4000 \mathrm{rpm}$ for $10 \mathrm{~min}$ and the supernatant was treated again with the mixture of chloroform and isoamylalcohol. The DNA was precipitated by the addition of two volumes of ethyl alcohol, spooled by a glass rod, and suspended in SSC. To the SSC solution, $\mathrm{NaCl}$ was added to the final concentration of $1 \mathrm{M}$ and the suspension was treated first with $1 \mathrm{mg} / \mathrm{ml}$ of Pronase (Kaken Kagaku Co. Tokyo) at $60^{\circ} \mathrm{C}$ for $4 \mathrm{hr}$, and then with $100 \mu \mathrm{g} / \mathrm{ml}$ of RNase I (Worthington Biochem. Co., U.S.A.) at $37^{\circ} \mathrm{C}$ for 30

8) L. J. Wickerhan, "Taxonomy of yeasts," Tech. Bull. U.S. Dep. of Agr., Washington, D.C. No. 1029 (1951).

9) D. Smith and H.O. Halvorson, "Methods in Enzymology," ed. by S.P. Colowick and N.O. Kaplan, Vol. 12, "Nucleic Acids," Part A, Academic Press, New York and London 1967, p. 538. min. The treatment with Pronase was repeated once again. To remove proteinous contaminants, the DNA was shaken with chloroform-isoamyl alcohol 3 to 4 times, and precipitated with 2 volumes of ethyl alcohol.

The crude DNA was purified on a methylated albumin-Kieselguhr (MAK) column which had been washed with $100 \mathrm{ml}$ of $0.55 \mathrm{M} \mathrm{NaCl}$ dissolved in $0.5 \mathrm{M}$ phosphate buffer, pH 6.8. Elution was made by an exponential gradient of $\mathrm{NaCl}$ from $0.55 \mathrm{M}$ to $1.5 \mathrm{M}$. Peak fractions were collected and dialyzed against SSC. The DNA was precipitated by the addition of ethanol and dissolved again in a small volume of SSC so that the final concentration became $250 \sim 400 \mu \mathrm{g} / \mathrm{ml}$. The solution was stored at $-20^{\circ} \mathrm{C}$. Purity of the DNA was above $95 \%$.

DNA's of $N$. crassa and Asp. oryzae were prepared by the following method: Cells were dried in cold acetone and disrupted in a mortal. DNA was extracted from the dried cells by incubation at $37^{\circ} \mathrm{C}$ for $4 \mathrm{hr}$ with 6 volumes of saline-EDTA-SLS. The DNA was purified by the procedures described above.

When ${ }^{32}$ P-labeled DNA was to be prepared, cells were cultivated first in $5 \mathrm{ml}$ of the phosphate-limiting medium at $30^{\circ} \mathrm{C}$ for $12 \mathrm{hr}$ and then in $50 \mathrm{ml}$ of the same medium containing $10 \mu \mathrm{Ci} / \mathrm{ml}$ of $32 \mathrm{P}$ (carrier free) for another $12 \mathrm{hr}$ at $30^{\circ} \mathrm{C}$. The labeled cells were treated in $10 \mathrm{ml}$ of $0.05 \mathrm{M}$ Mcllvaine's buffer (pH 5.8) containing $0.6 \mathrm{M}$ sucrose with $1 \mathrm{mg} / \mathrm{ml}$ of the snail enzyme (supplied from Dr. S. Iguchi, Ibaragi Univ.) and resulted spheroplasts were suspended in $10 \mathrm{ml}$ of saline-EDTA-SLS. The cells were disrupted in a sonic oscilator at $9 \mathrm{kc}$ for $10 \mathrm{~min}$, and then the homogenate was heated at $60^{\circ} \mathrm{C}$ for $10 \mathrm{~min}$. 32P-DNA was extracted by the phenol method which was followed by the RNase digestion. The DNA was further purified on the MAK column and peak fractions were subjected to the dialysis against SSC.

Hybridization experiments. DNA-agar was prepared by the Bolton and McCarthy's method according to the procedures described by Takahashi et al.101 Modifications made were: $160 \mathrm{mg}$ of agar-agar were used for $5 \mathrm{~g}$ of DNA-agar-gel; $0.3 \mathrm{ml}$ of $2 \times \mathrm{SSC}(0.3 \mathrm{M} \mathrm{NaCl}$ and $0.03 \mathrm{M} \mathrm{Na} \mathrm{Na}_{3}$-citrate) containing $0.05 \sim 1.5 \mu \mathrm{g}{ }^{32} \mathrm{P}$ DNA (ca. $10^{4} \mathrm{cpm} / \mu \mathrm{g}$ ) was used for $200 \mathrm{mg}$ of DNA agar-gel and the mixture was incubated at $60^{\circ} \mathrm{C}$ for $16 \sim 20 \mathrm{hr}$. Unhybridized portion was removed by

10) H. Takahashi, H. Saito and Y. Ikeda, J. Gen. Appl. Microbiol., 12, 113 (1966). 
washing with $2 \times \mathrm{SSC}$, and radioactivity in the agargel was counted in a thin window gas flow counter (Nippon Musen Co., Tokyo).

Chemical and instrumental analysis. RNA and protein were measured with orcinol and phenol reagents, respectively. The concentration of DNA was determined spectrophotometrically by measuring the optical density (O.D.) at $260 \mathrm{~m} \mu$; one O.D. unit corresponded to $50 \mu \mathrm{g}$ of native DNA and $36 \mu \mathrm{g}$ of denatured DNA.

DNA was heated in SSC and the thermal denaturation curves were made by use of a spectrophotometer equipped with an automatic recorder (Gilford Co., U.S.A.).

$\mathrm{CsCl}$ density gradient analysis was made by a Spinco Model E ultracentrifuge using SW 39 rotar. The rotar was run at $33,450 \mathrm{rpm}$ for $66 \mathrm{hr}$. Six drop fractions were collected from the bottom of the tube and served for the assay of radioactivity.

\section{RESULTS}

\section{Homogeneity of the isolated DNA}

Figure 1 shows an elution profile of DNA of $S$. cerevisiae IAM 4009 from the MAK column. The profile suggests that the DNA may consist of at least two classes of DNA molecules with different GC contents. Each fraction was dialysed against SSC and served for the thermal denaturation experiment. As shown in Fig. 2, the DNA from the earlier fractions gave a uniphasic curve, but the DNA from the shoulder portion a biphasic curve.

Corneo et al. ${ }^{11}$ have described that yeast cells cultivated under aerobic conditions contain a considerable amount of mitochondrial DNA (10 to $14 \%$ of the total DNA), ${ }^{11,121}$ and Tewari et al. ${ }^{13 \prime}$ have presented a thermal transition profile similar to that in Fig. 2. It is generally thought that the GC content in mitochondrial DNA of yeast is lower than

11) G. Corneo, C. Moore, D. R. Sanadi, L. I. Grossman and J. Marmur, Science, 151, 687 (1966).

12) J. C. Mounlou, H. Jakob and P. P. Slonimsky, Biochem. Biophys. Res. Commun., 24, 218 (1966).

13) K.K. Tewari, W. Vötsch and H. R. Mahler, J. Mol. Biol., 20, 453 (1966).

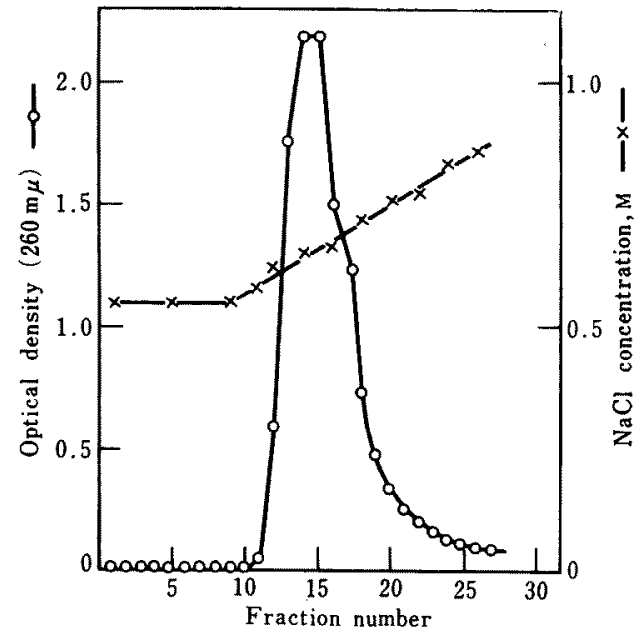

FIG. 1. Elution Profile of $S$. cerevisiae-IAM 4009DNA from MAK Column.

One mg of DNA was loaded on the column equilibrated with $0.05 \mathrm{M}$ phosphate buffer $(\mathrm{pH}$ 6.8 ) plus $0.55 \mathrm{M} \mathrm{NaCl}$. Elution was made with an exponential gradient of $\mathrm{NaCl}$ (between $0.55 \mathrm{M}$ and $1.5 \mathrm{M}$, each $250 \mathrm{ml}$ ) dissolved in the phosphate buffer. Five $\mathrm{ml}$ fractions were collected.

that in chromosomal DNA. ${ }^{11 \sim 13}$

The ${ }^{32} \mathrm{P}$-labeled DNA of $S$. cerevisiae IMA 4009 also gave an elution profile similar to that in Fig. 2. Under the expectation that the DNA from the earlier fractions (e.g. tube numbers $12 \sim 14$ ) might contain no or a little amount of mitochondrial DNA, the fractions were used for the hybridization experiments.

Homogeneity of the ${ }^{32} \mathrm{P}-\mathrm{DNA}$ preparation was confirmed by the CsCl density gradient centrifugation. Figure 3 shows the sedimentation profiles of DNA from $S$. cerevisiae IAM 4009 and $C$. pulcherrima IFO 0561. The GC contents were calculated from the buoyant densities according to the equation presented by Schildkraut et al. ${ }^{14}$ and the values obtained for $S$. cerevisiae-DNA and $C$. pulcherrima-DNA, $41.8 \%$ and $48.0 \%$, respectively, were approximate to those reported by other investigators. $^{3,6,111}$

14) C. L. Schildkraut, J. Marmur and P. Doty, J. Mol. Biol., 4, 430 (1962). 


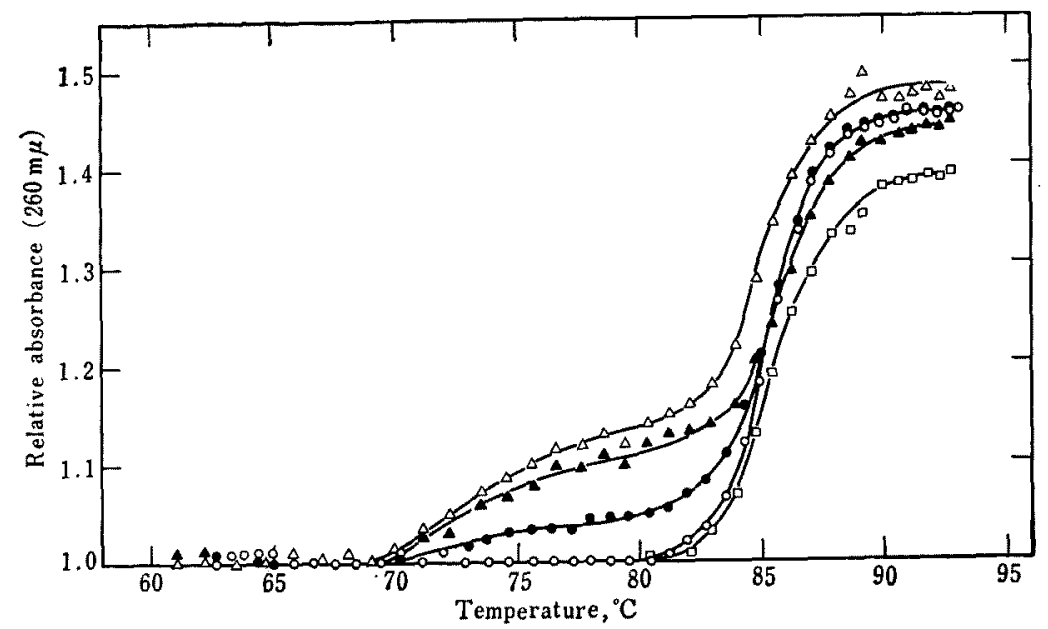

FIG. 2. Thermal Denaturation Curves of the DNA Fractionated by the MAK Chromatography.

Each fraction was dialyzed against SSG and the DNA concentration was adjusted to 0.5 O.D. $260 \mathrm{~m} \mu$ units. Denaturation curves were made by a spectrophotometry with the Gilford automatic recorder.

A No. 19, $\triangle$ No. 17, No. 16, O Nos. 14 and 15, $\square$ No. 12.

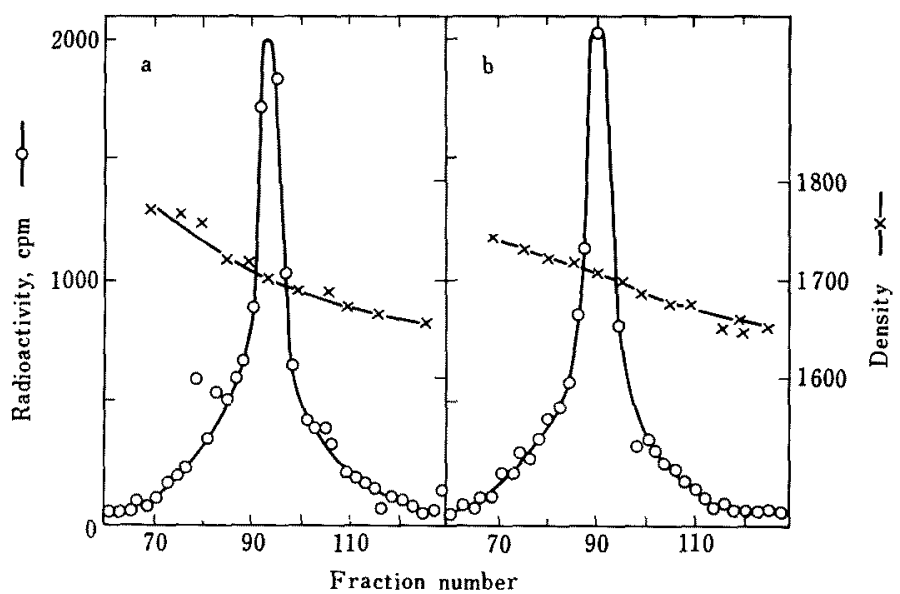

FIG. 3. CsCl Density Gradient Centrifugation of Purified DNA's of S. cerevisiae IAM 4009 (a) and of C. pulcherrima IFO 0561 (b).

Twenty $\mu \mathrm{g}$ of DNA in SSC was mixed with $\mathrm{CsCl}$ so that the final density became $1.70 \mathrm{~g} / \mathrm{cm}^{3}$. The solution was centrifuged at $33,450 \mathrm{rpm}, 20^{\circ} \mathrm{C}$ for $66 \mathrm{hr}$ in a SW 39 rotar of the Spinco Model E ultracentrifuge. Six drop fractions were collected and served for the assay of radioactivity by a GM counter.

The GG contents of DNA in other strains denaturation curves (Table II). were calculated according to the equation presented by Marmur et al., ${ }^{151}$ from the thermal

15) J. Marmur and P. Doty, J. Mol. Biol., 5, 109 (1962).

DNA homology examined by hybridization method

Control experiments for hybridization were carried out between a definite amount of cold 


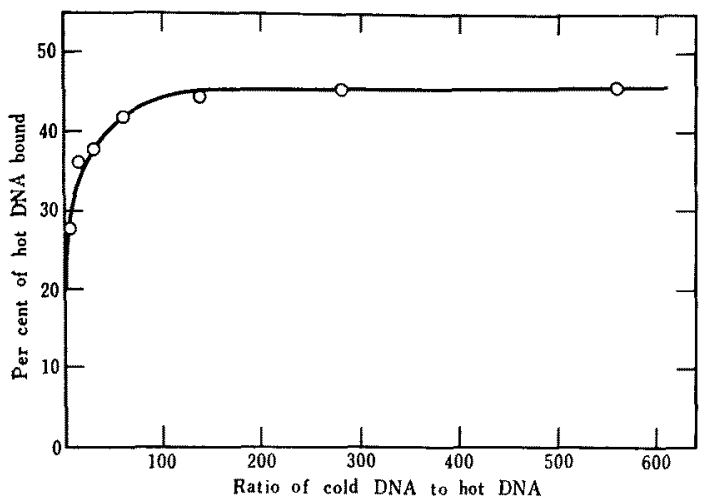

FIG. 4. Saturation Level of DNA in Agar-gel.

Two hundred mg of DNA-agar containing $13 \mu \mathrm{g}$ of DNA of $S$, cerevisiae IAM 4009 were incubated at $60^{\circ} \mathrm{C}$ for $20 \mathrm{hr}$ with decreasing amounts of 32P-labeled DNA $(25,000 \mathrm{cpm} / \mu \mathrm{g})$ of the same strain.

DNA of $S$. cerevisiae IAM 4009 and decreasing amounts of ${ }^{32} \mathrm{P}$-labeled DNA of the same strain (Fig. 4). Fractions of ${ }^{32} \mathrm{P}$-labeled DNA trapped on the agar-gel increased with the increment of cold to hot ratio and the curve reached a plateau at a ratio of $1: 100$. In later experiments, ratios of $1: 100,1: 200$ and 1:400 were chosen and the results were expressed as means of three data obtained at the plateau levels.

Interspecies hybridizations were performed between hot DNA of $S$. cerevisiae IAM 4009 and cold DNA of other strains. The term homology index implies relative recovery percentage of the hot DNA from heterologous combination compared to recovery percentage of the hot DNA from isologous combination. Table I shows results of three experiments obtained by use of independently prepared DNA. The homology indices deviated considerably from experiment to experiment, but the deviation was not so large as to disturb the proper evaluation of the species specificity of DNA.

The last column of the table shows results of the hybridization experiment carried out between ${ }^{32} \mathrm{P}$-labeled DNA of $C$. pulcherrima
TABLE I. HybRIdization OF LABeled DNA OF Saccharomyces cerevisiae IAM 4009 OR Candida Pulcherima IFO 0561 WITH COLD DNA OF VARIOUS MICROORGANISMS

A mixture consisted of $200 \mathrm{mg}$ of DNA-agar, which contained $10 \sim 20 \mu \mathrm{g}$ cold DNA of each tested strain, and $0.3 \mathrm{ml}$ of $2 \times \mathrm{SSC}$, which contained $32 \mathrm{P}$-labeled DNA $(15,000 \sim 25,000 \mathrm{cpm} / \mu \mathrm{g})$ of $S$. cerevisiae IAM 4009 or C. pulcherrima IFO $056 \mathrm{1}$, was incubated at $60^{\circ} \mathrm{C}$ for $16 \sim 20 \mathrm{hr}$. The agar-gel was washed with $2 \times$ SSC at $60^{\circ} \mathrm{C}$ and the radioactivity remained in the gel was counted. The percent of remained DNA to input DNA was $40.4 \%$ for Exp. 1, $44.7 \%$ for Exp. 2, or $46.9 \%$ for Exp. 3 when the hot and cold DNA's were prepared from $S$. cerevisiae, and $28.5 \%$ when the hot and cold DNA's were from $C$. pulcherrima.

\begin{tabular}{|c|c|c|c|c|}
\hline \multirow{3}{*}{ Microorganisms ${ }^{5}$} & \multicolumn{4}{|c|}{ DNA homology index $x^{a)}, \%$, to } \\
\hline & \multicolumn{3}{|c|}{ S. cerevi. IAM 4009} & \multirow{2}{*}{$\begin{array}{c}C . \\
\text { pulcher- } \\
\text { rima } \\
\text { IFO } \\
0561\end{array}$} \\
\hline & $\underset{1}{\operatorname{Exp}}$ & $\underset{2}{\operatorname{Exp}}$ & Exp. & \\
\hline S. cerevisiae IAM 4009 & 100 & 100 & 100 & 12 \\
\hline S. cerevisiae L 8256 & 66 & 57 & & 11 \\
\hline S. cerevisiae IAM 4518 & 69 & 55 & 64 & 11 \\
\hline $\begin{array}{l}\text { S. carlsbergensis IAM } \\
4206\end{array}$ & 43 & & 36 & 9 \\
\hline S. fragilis IAM 4763 & 20 & 15 & & 10 \\
\hline S. rouxii IAM 4028 & 11 & 11 & & \\
\hline S. pastori IFO 1013 & 16 & & & 12 \\
\hline $\begin{array}{l}\text { P. membranaefaciens IAM } \\
4025\end{array}$ & 18 & 12 & & 9 \\
\hline H. anomala IAM 4213 & 14 & & 11 & 10 \\
\hline D. kloeckeri AHU 3420 & 13 & 10 & 11 & 10 \\
\hline Sch. actosporus IAM 4842 & 13 & 11 & & \\
\hline C. pulcherrima IFO 0561 & 10 & 11 & 8 & 100 \\
\hline C. rabusta IFO 0718 & 55 & & 59 & 9 \\
\hline T. colliculosa IFO 0381 & 22 & & 15 & 10 \\
\hline $\begin{array}{l}\text { Neurospora crassa IFO } \\
6067\end{array}$ & 7 & & 6 & 9,10 \\
\hline Aspergillus oryzae $\mathrm{I}$ & 5 & & & 3,5 \\
\hline Escherichia coli B & 1.5 & & 1 & 0 \\
\hline Calf thymus & 3.5 & & 1.5 & 0 \\
\hline None & 0 & & 0 & 0 \\
\hline
\end{tabular}

a) The relative recovery persentage of hot DNA from heterologous combination compared to that of hot DNA from isologous combination.

b) S: Saccharomyces; P: Pichia; H: Hansenula; $D$ : Debaryomyces; Sch: Schizosaccharomyces; $C$ : Candida; $T$ : Torulopsis; IAM: Institute of Applied Microbiology, Univ. of Tokyo; L: Carbondale strain given by Dr. C.C. Lindegren; IFO: Institute for Fermentation, Osaka; AHU: Faculty of Agriculture, Univ. of Hokkaido, Sapporo.

c) 32P-DNA used for Exp. 3 had been purified by the $\mathrm{CsCl}$ density gradient ultracentrifugation (fraction No. $90 \sim 98$ in Fig. 3a). 
IFO 0561 and cold DNA of other strains. $C$. pulcherrima was chosen as a reference because the GC content of the DNA was the highest among the tested strains, and also because DNA of this strain hybridized scarcely with that of another reference, $S$. cerevisiae IAM 4009. None of the tested strains showed high DNA-homology with C. pulcherrima IFO 0561.

\section{Confirmation of DNA homology by competition method}

The hybrid formation between hot and cold DNA's of $S$. cerevisiae IAM 4009 was tested in the presence of large amounts of homologous and heterologous DNA. As shown in Fig. 5, DNA from closely related strains inhibited the hybrid formation significantly, but the inhibitions by DNA from less-related strains were small.

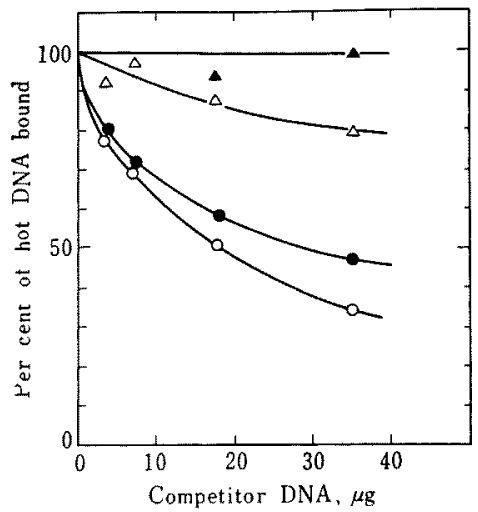

FIG. 5. Competitive Effects of Isologous and Heterologous Cold DNA's on the Formation of Isologous Hybrid.

An annealing mixture contained $13 \mu \mathrm{g}$ of cold DNA of $S$. cerevisiae IAM 4009, and $0.7 \mu \mathrm{g}$ of ${ }^{32} \mathrm{P}$-labeled DNA of the same strain. The hybridization was carried out in the presence of increasing amounts of cold- $S$. cerevisiae IAM 4009-DNA $(O-$ O) S. cerevisiae L 8256-DNA (-), C. pulcherrima IFO 0561-DNA $(\triangle-\triangle)$ or $E$. coli B-DNA $(\boldsymbol{\Delta}-\mathbf{\Delta})$. The reaction mixture was incubated at $60^{\circ} \mathrm{C}$ for $20 \mathrm{hr}$. The radioactivity remained in the DNAagar was assayed after being washed with $2 \times \mathrm{SSC}$ and expressed as percent radioacitivity of the control, which was $44.2 \%$ of input hot DNA.

\section{DISCUSSION}

Strains used in the present study, except for Schizosaccharomyces octosporus, belong to either tribe Saccharomyceteae or subfamily Cryptococcoideae. " The GC contents of the DNA in these strains range between $36 \sim 47 \%$ and the DNA homology indices between 10 100\%.

Two strains of $S$. cerevisiae, L 8256 and IAM 4518, show homology indices of 55 70\%. Strain L 8256 is a Carbondale strain. As this strain has been used for a long period for genetic studies, genetic purity of the strain is doubtful. Strain IAM 4518 and the reference strain IAM 4009 were supplied from the Division of Type Culture Collection of this

Table II. Genetic Relatedness of Yeast STRAINS VIEWED FROM THREE ASPECTS

\begin{tabular}{|c|c|c|c|}
\hline Strains & $\begin{array}{c}\text { DNA } \\
\text { homology } \\
\text { index, } \%, \\
\text { to } S . c . \\
4009 a\end{array}$ & $\begin{array}{c}\mathrm{GC} \% \text { of } \\
\mathrm{DNA}^{b}\end{array}$ & $\begin{array}{l}\text { Serologi- } \\
\text { cal } \\
\text { group }\end{array}$ \\
\hline S. cerevisiae IAM 4009 & 100 & 39.5 & II \\
\hline S. cerevisiae L 8256 & $57 \sim 66$ & 39.5 & II \\
\hline S. cerevisiae IAM 4518 & $855 \sim 69$ & 39.5 & II \\
\hline C. robusta IFO 0718 & $55 \sim 59$ & 39.5 & II \\
\hline $\begin{array}{l}\text { S. carlsbergensis IAM } \\
4206\end{array}$ & $36 \sim 43$ & 39.5 & II \\
\hline S. fragilis IAM 4763 & $15 \sim 20$ & 40.5 & II \\
\hline S. rouxii IAM 4028 & $11 \sim 11$ & & II \\
\hline S. pastori IFO 1013 & 16 & 42 & III \\
\hline $\begin{array}{l}\text { T. colliculosa IFO } \\
0381\end{array}$ & $15 \sim 22$ & 43 & VII \\
\hline $\begin{array}{l}\text { P. membranaefaciens } \\
\text { IAM } 4025\end{array}$ & $12 \sim 18$ & 37 & III \\
\hline H. anomala IAM 4213 & $3 \quad 11 \sim 14$ & 36 & IV \\
\hline D. kloeckeri AHU 3420 & $010 \sim 13$ & 36 & $\mathrm{~V}$ \\
\hline $\begin{array}{l}\text { C. pulcherrima IFO } \\
0561\end{array}$ & $8 \sim 11$ & 47 & VI \\
\hline $\begin{array}{l}\text { Neurospora crassa IFO } \\
6067\end{array}$ & 7 & 50 & \\
\hline Aspergillus oryzae 1 & 5 & & \\
\hline Escherichia coli B & $1 \sim 1.5$ & 52 & \\
\hline Calf thymus & $1.5 \sim 3.5$ & 42 & \\
\hline
\end{tabular}

a) Summary of Exp. $1 \sim 3$ in Table I.

b) GC $\%$ was calculated from the thermal transition profiles.

c) From Tsuchiya et al.2. 
Institute. We do not know which of the above-stated three strains can be regarded as the authentic culture of $S$. cerevisiae. Anyway, the DNA homology indices diversed largely among the three $S$. cerevisiae strains in spite of the similar GC contents.

$S$. carlsbergensis is a species known to be able to mate with the Carbondale strain of S. cerevisiae. ${ }^{16)}$ Homology index of this strain is $36 \sim 43 \%$, and may be corrected to $70 \sim 80 \%$ by taking the index of strain L 8256 as $100 \%$. The correlation between homology indices and mating compatibilities is an interesting subject worthwhile to be studied further.

Other Saccharomyces species show considerably low homology indices. $S$. pastori is a species classified by Phaff ${ }^{17}$ into Pichia. The homology index of this strain is only $16 \%$ of that of $S$. cerevisiae IAM 4009. Tsuchiya et $a .^{23}$ have described that $S$. pastori can be discriminated from other Saccharomyces species by the serological method.

Candida robusta exhibits a relatively high homology index. This species may be an imperfect form of $S$. cerevisiae as have been stated by Lodder and Kregar-van-Rij." The

16) C. C. Lindegern, S. Spiegelman and G. Lindegern, Pro. Nat. Acad., Sci., 30, 346 (1944).

17) H. J. Phaff, Antonie van Leeuwenhoek, 22, 114 (1956). serological and genetic studies made by Tsuchiya et al..$^{2,18}$ have supported the view. Torulopsis colliculosa has also been reported to be an imperfect form of $S$. fermentati, but according to our study the homology index is $15 \sim 22 \%$.

Another interest in the present study is the lower extreme of the homology indices. It is about $10 \%$ in the so-called yeasts. Takahashi et al. have published an opinion ${ }^{19}$ that bacterial DNA may consist of species-specific portion and interspecies-common portion (conserved portion such as ribosomal RNA cistrons). If this view can be extended to fungal DNA, the residual homology, about $10 \%$, observed in the present study may represent the interspecies-common DNA. The DNA's from $N$. crassa and Asp. oryzae show homology indices of $5 \sim 7 \%$. If these values also represent the conserved portion in fungal DNA, it may be speculated that the DNA conservation is considerably larger in fungi.

This work was supported by a Research Grant from the Ministry of Education.

18) T. Tsuchiya, Y. Fukazawa, 1. Sato, S. Kawakita and J. Katsuya, Japan J. Exp. Med., 28, 413 (1958).

19) H. Takahashi, H. Saito and Y. Ikeda, Biochim. Biophys. Acta, 134, 124 (1967). 